\title{
Character and the Moral Self in Barack Obama's Memoir, Dreams from My Father
}

\author{
Ernest Washington ${ }^{1}$, Elham Zandvakili $^{2} \&$ Edmund Gordon ${ }^{3}$ \\ ${ }^{1}$ Professor, Emeritus, University of Massachusetts, Amherst, Department of Teacher Education \& Curriculum \\ Studies, USA \\ ${ }^{2} \mathrm{PhD}$ Candidate, University of Massachusetts, Amherst, in Language Literature and Culture in the College of \\ Education, USA \\ ${ }^{3}$ Professor, Emeritus - Yale University, Department of Psychology, USA \\ Correspondence: Elham Zandvakili, PhD Candidate, University of Massachusetts, Amherst, in Language \\ Literature and Culture in the College of Education, USA
}

Received: August 5, 2018

doi:10.5539/ijps.v10n3p109
Accepted: August 30, 2018

Online Published: August 31, 2018

URL: https://doi.org/10.5539/ijps.v10n3p109

\begin{abstract}
Barack Obama is the subject and his memoir is the content for this essay on character and the moral self. These last two themes are applied to the development of Barack Obama's character traits of love and caring, temperance, courage, love of learning, justice, and spirituality. Each character trait is valued, practiced worldwide and praised in children and adults. This analysis answers a question that has eluded scholars and political pundits. How was it possible for Barack Obama to understand that whites would vote for him to become president of the United States? The answer is hidden in plain view in the development of his character and moral self. This essay provides insights into how his character prepared him to become President of the United States.

A practical model of character development is an important aim of this essay. Character is habits of mind and body that persist over time. The development of the moral self is a frame for understanding the role of emotions and cognition in the cultivation of habits of mind. Understanding the character of Barack Obama is only partial vindication of a model of the development of character. A supremely talented Barack Obama makes any model look good. The test of the usefulness and validity of the model is that it provokes the reader to think about children, especially African-American children in all of their uniqueness and universality. A conversation that begins with the habits of love and caring, temperance, courage, love of learning, justice, and spirituality is a good beginning toward that end.
\end{abstract}

Keywords: love and caring, temperance, courage, love of learning, justice, and spirituality

\section{Introduction}

Barack Obama took the oath of office of the President of the United States on January 20, 2009. How did this happen? His spectacular rise to the pinnacle of power is the political story of the $21^{\text {st }}$ century. This essay identifies and explores the character strengths and the moral self that made his spectacular journey possible. Included within his story is a model that reveals the development of character and the moral self. January 2008 a little known junior senator from Illinois, Barack Obama, announces his candidacy for the presidency. He said the odds were impossibly large. This son of a white mother from Kansas and a Kenyan father had an improbable vision. He was a constitutional scholar, grounded in the history and traditions of the American experience. He should have known better. How is it possible for an African-American to be elected President of the United States of America? At best, he was a presumptuous opportunist. At worse, it was a fool's errand. The blueprints for his spectacular success are in his memoir, Dreams from My Father. A rereading of his memoir reveals the underlying truths that guide him through uncharted moral spaces and liberate him to see the world differently.

A century before W.E.B. Dubois looked-across the racial divide in America, and declared the $20^{\text {th }}$ century, the century of the color line. Barack Obama bridges the racial gap in a way Dubois did not anticipate. Obama embodies the racial divide, and tells a story few understand. Physically, mentally, and morally he is the color line. His biracial background and cultural experiences are a compelling story of the racial divide and the search for community. His biracial background bridges a complex and conflicted world. His white and black experiences are not at odds. With sadness, he notices other biracial and multiracial individuals do not celebrate their 
blackness and avoid blacks. They are not conscious of the movement away from blacks. Obama likens the movement and preference for whiteness to a gravitational pull of the larger culture upon a smaller. How did he free himself from the pull of racism?

Character and a moral self liberate Obama to see the world without the blinders of race in America. The cultivation of love and caring, temperance, courage, love of learning, justice, and spirituality are the foundations of his success. His moral self originates in the subtle, fleeting feelings constructed in temporal relations with his mother. Baby and mother are a continuing and pulsating emotional experience interrupted by their rhythmic needs. From this rhythm emerges the feeling of righteousness, of comfort, of having a full belly, and warmth. A pulsating emotional and physical synchrony between mother and son brings comfort, temporality, and the origins of the moral self. Babies live their lives in the whole, and experience it as a living embodiment of the present. Now is when the child's needs are being met and is the present.

His moral self is engaged in solving the moral problems of everyday life. The moral self consists of the stories that he tells about himself and the stories that others tell about him. Moral stories are narratives of the past, present, and future in which "I" make moral choices. The moral self includes episodic memories of his life, memories of his personality, personal history, the experience of personal agency, continuity in time and space, and the ability to reflect on thoughts and feelings. These different functions are unified in the narratives of everyday life. The moral self is the author of a narrative set in a changing, contradictory, and dangerous moral world. Signs and signals are all about in this unpredictable world. The moral emotions are the tools that inform making choices in this moral world.

What gave Barack Obama the prescient insight he could be president? The answer is simple and hidden behind the veil of racism. It is open to public view but is so improbably, no one sees it.

He is without prejudice toward blacks or whites! He loves whites and blacks and not simply in passing. His love of blacks and whites is possible because he has known the love and embrace of each. He is loved and loves in return whites and blacks in the round, in a way that we all only hope someone will love us one day. Love brings a trust that you will love and trust in return. Racism makes it all but impossible to find unconditional love from whites and blacks in a racially polarized world. When love tilts toward one race, there is an imperceptible antipathy toward the other race. In Obama's word, it is a "gravitational pull" of the larger force against the smaller. His moral self liberated him to feel that whites would vote for him to become President of the United States.

\section{Stages of Character and the Moral Self}

\section{In dreams from my father}

Obama's memoir, written two years after graduation from The Harvard Law School and five years before he is elected to public office, is an opportunity to reflect upon character, his moral self, and to sharpen his thinking in a way only accomplished through writing. The moral self bridges the complexities and divisions in the world as he continually compares the different worlds through his imagination. He comments in the preface to his memoir, "I went to work on Dreams with the belief that the story of my family, and my efforts to understand that story, might speak in someway to the fissures of race that have characterized the American experience, as well as the fluid state of identity - the leaps through time, the collision of cultures, that----that mark our modern life." With this summary Obama uses the essential tools of the moral self and character to fashion the most astute analysis of African-American life in the past several decades. Not since Malcolm $X$ has a rhetorical text by an African-American political figure illuminated dreams, family stories, and the paths to political and economic liberation.

Dreams From My Father divides into three parts with different patterns of character development. The first third of the memoir, Origins, is a narrative about character development from early childhood to young adulthood. Much of this part of the memoir is of his early memories. His moral imagination takes him to Honolulu, Jakarta, California and New York City and gives him a rich repertoire of multicultural experiences upon which to construct a resilient and coherent story of his life. He emerges from this first part of his life as a recent graduate of Columbia University and ready to take his first job. Chicago is the title and second section of the memoir, and documents his search for a sense of community. He works as a community organizer, and finds community in a small group of activists who share a moral vision, actions and the achievement of social justice. As a result of his work with his community supporters, "Obama's army", he achieves what he never had before, his first connections in an African-American community. Obama is now ready to move on to Law School and Harvard University. Kenya, the conclusion of the memoir, is a narrative of his return to the land of his father's birth and death and the land of his grandfather. His moral imagination takes him on mental time travels to his past and 
distant past. At the end of his journey he finds not the understanding of the particulars of his life but the spiritual insights to be a decent human being.

The first part of Dreams is Obama's story of the development of his character and moral self. A theory of character and the moral self are scattered and embedded in his memoir, and in this essay, his views are placed into a different theoretical context. This rearrangement of content and a different purpose means, of course that the facts are Obama's and the theory is the author's. The intention of this essay is not to repeat what Obama has to say but to show that his memoir illuminates the universals in human development but also speaks to the American experience in a way not heard before.

Obama's discussion of character is shaped by his familiarity with the Aristotelian virtues and this is expected from an intellectual who is well read and self-reflective. According to Martha Nussbaum Aristotle's list of the virtues is carefully drawn to isolate a sphere of human experiences (a setting) that figures in more or less any human life and the dispositions to act appropriately in a setting. Nussbaum's list of virtues includes courage, moderation, justice, generosity, expansiveness, hospitality, greatness of soul, mildness of temper, truthfulness, easy grace, friendliness, proper judgment, love of knowledge and wisdom. This rather long list is reduced to the virtues of love and caring, temperance, courage, justice, love of knowledge, and transcendence.

The virtues are acquired by repetition of the corresponding activity, and are habits of mind and body. Activity, acting in the world, is the path to the virtues. Plumbers become plumbers by plumbing, violin players become violin players by playing the violin, we become just by doing just acts, temperate by doing temperate acts, and compassionate by doing compassionate acts. The virtues are grounded in the activities of daily life, and action is the conduit to character.

A memoir is an author's view of his or her past, present, and future. A personal story is a dynamic and tumultuous process because the past, present, and future are constantly in flux and change. Memories of the past are not a film we recall seeing, and are more like a constantly changing collage of experiences. Barack reminds us that the past is never past. The past is always intruding into the present and changing the way that we see the world. The present is constantly shifting and moving as attention turns in one temporal direction and then another. The present is a place from which we look back upon the past or forward into the future. The future is imagination and the part of the story yet to be written. The moral self is a tool that fashions understanding of the past, present, and future seamlessly into a coherent story.

\section{Stage 1: Humanity: Love and Caring}

Humanity is the first of the character traits and love and caring are the foundation. Love and caring are patterns of living with many forms: filial love, romantic love, sibling love, and love of country are but a few examples. Love is the emotion, and caring is the activity. It is one thing to love a baby, it is quite another to do the hard work each day that makes a mom or dad.

Barack's narrative of his infancy recounts the warm and loving memories of his mother and grandparents. He has no linguistic memory of his infancy because the cognitive and emotional substrates for memory have not yet matured. His memories of his infancy and early years are the residue of the stories that he has been told. From this millage of his feelings and the stories that he has heard, he constructs a story of his infancy. His father abandoned him and his mother. The moral self weaves his mother and grandparents love and his absent father into a coherent story. His mother was frequently absent when he was growing up, and he bounced from Honolulu to Jakarta and back to the loneliness of the Pounohou Prep School. He remained resolutely resilient because of the love of his mother and grandparents. He says that his mother exerted the greatest influence upon him. He loves his mother, no doubt. It is a love that grows stronger when the loved one is not there. His father's absence leaves a void where a man was not. Obama comments that he does not remember the conversations with his father, he can recall only the images. Michelle's interpretation is that boys and their fathers don't have very much to say to each other until they trust each other.

The rhythms of love and caring ripple through the years influencing all of later development. Barack learns the character traits of love and caring during his early years with his mother and grandparents. He describes love this way. "That's how my love begins, impulses and cloudy images that allow us to break across our solitude, and then, if we're lucky, are finally transformed into something firmer." Barack is an only child and his mom and grandparents shower love and caring upon him, and are securely attached to him, and he to them. Their mutual emotional attachments nurse deep feelings of love and firm caring. He sees the world through their eyes. Their happiness is his happiness and their joy is his joy. The trust in his mom and grandparents are all he needs when he begins to explore the world. His curiosity expands as the world responds to him and is at his call. Love grows out of attachments and allows him to reach out and love others. 
Caring is emotionally laden activities he shares with his grandparents. They sacrificed their lives for him. The word and the practice of sacrifice are not in fashion today. The word sacrifice comes from the word, sacred. Caring motivated his grandmother to go to a job every workday to a bank that did not promote her because she was a woman. Caring motivated his grandfather to have a career in sales and business and to keep trying and trying. The dreams for economic success faded for his grandparents but they kept working and struggling because they cared for him. Caring is the most general of the emotions, when we care we take on the responsibility to make the lives of others better. Caring is misunderstood as simply a "wimpy" emotion. When we care we take responsibility to make the other person better. It is a responsibility that is taken personally, and presupposes personal engagement. Caring describes the ferociousness of the tiger when her cubs are threatened, and the sacrifices parents make for their children (Solomon, 1995).

Barack Obama's moral self begins in the dynamics of the flood of memories and emotions in infancy. At the heart of his being are his preconscious images and memories of his mother and grandparents. Their shared love precedes language. Individual morality begins when temporality begins. Temporality is the first inkling, the first feeling of a sense of self. It marks the beginnings of the child's recognition that it has a physical body. The infant is unable to regulate the physical body, control arms, legs, and head. The moral self goes through a developmental series beginning with the first recognition of separation from the mother. The rhythms of this primal relationship are at the base of being, and echo through the coming years of development. Emotions and temporality give way to the emergence of the moral self.

His moral self grows and changes as Barack tells and lives stories of increasing temporal and moral perplexity. In infancy, his sense of right and wrong is the experience of the present. As a three-year-old he tells a story that connects the past and the present. The concrete minded elementary school child lives in the present, discounts the past and makes concrete plans for the future. As an adolescent he connects the pasts, present, and future but loses his way between the present and the future consequences of his actions. With maturity, the moral self-balances the past and plans for the future to make the most coherent story and the appropriate moral decision at the time. Conflicting images from the past, present, and future merge into a new image and a new story.

The subjective experience of temporality begins in the rhythmic emotional relationship between mother and child, and reaches completion in narratives of the past, present, and future. The heartbeat of temporality is the clashing and changing of emotions in the early rhythms of the human experience. Early in infancy the natural rhythms of hunger and satisfaction alternate in search of a common rhythm between mother and child. The search for warmth and touch along with ingestion and elimination give a rhythm to life as the child slowly recognizes the cycles of night and day. With these processes come feelings of satisfaction, completion, and joy. The infant struggles for equilibrium between its physical needs and its caregivers. From a baby's perspective, the categories of the past and present are blurry, fluid and translucent. The perception of temporality emerges, as children grow older. When young children wake from naps they are not sure if it is the next day. Awareness of the categories of time becomes prominent in the years to come.

Love and caring make resiliency possible. The benefits of love and caring are easily understood with a negative question, what are the consequences of not being loved as an infant? Children who are not loved as infants are at risk personally, socially, and morally. The connection between infant and mom is powerful and when ruptured, causes serious consequences. A feeling of profound loss and aloneness comes about when the child is separate from her mom. The child is angry, disappointed, and in need of love and caring. The separations from his mother strengthened Barack's love for his mother. In the interim periods his grandparents are there for him. Their caring is the something firmer" that Obama describes in his description of love.

Obama's love is transformative. It is a love that reaches across the racial divide in America, and it is a gift a unique gift, of America to itself. He embodies what has been unthinkable before, love across the racial divide. Of course, many millions have discovered and experienced love and interracial relationships. Obama is the first to reach successfully for the pinnacle of political achievement. He is as much European American as he is African American, and yet there is little acknowledgement or appreciation of his European American heritage. Yet because of his bi-racial heritage he has a perspective and understanding on race that is different from those on either side of the racial divide. This understanding penetrates to the core of his being. The evidence for it is here.

"I heard from my mother that day, speaking about my father something that I suspect most Americans will never hear from the lips of those of another race, and so cannot be expected to believe might exist between black and white, the love of someone who knows in the round, a love that will survive disappointment. She saw my father as everyone hopes at least one other person might see him; she had tried to help the child who never knew him to see him in the same way. And it was the look on her face that day that I could remember when a few months alter I called to tell her that my father had died and heard her cry out over the distance (p. 127). 


\section{Stage II: Temperance and Self-Control}

His mom and grandparents teach him temperance. He sees temperance in his grandparents as their dreams came to so little. In spite of disappointments and loss they did not give into bitterness and regret, their love for him and the "stoicism" of their ancestors kept them going. Obama inherits this stoicism and it is transmuted into a steely self-control. If his memoir is a testament to his temperance then he is an author with a disposition toward moderation.

The Aristotelian version of temperance is moderation with a focus on the control of the impulses of the body. Self-control is respected across cultures, and is one of the cardinal virtues in ancient Greece. The National Research Council (2000) argues that self-regulation is the foundation of cognitive and emotional development and a gateway to schooling. There is great research interest in self-regulation because it predicts not only success schooling but also the use of alcohol and other drugs. Researchers consistently find that self-control at ages three and four predicts risks and achievement one and two decades later. Children have very few memories of the first two years of life. This lack of memory is called childhood amnesia. As a consequence, much of the learning experiences is in the unconscious and emotional.

Temperance and self-control grow out of the regularities of infant love and caring. The rhythms of everyday life of infants with its continuing surges of needs and satisfactions influence the emergence of temperance and self-control. The cycles of hunger and satisfaction, waking and sleeping, crying and calm, being held and comforted are habits that are the foundations of later development.

Obama's moral self grows along with his love for his mother. She was direct in cultivating his sense of conscience. She made him feel guilty; this was a trick that always worked. "She made no bones about it either, "You can't help it," she told me once. "I slipped it into your baby food. "Don't worry though, "she added smiling like a Cheshire cat. "A healthy dose of guilt never hurt anybody. It's what civilization is built on, guilt. A highly underrated emotion." The single most important influence in his life is the way he describes his mom.

The moral self synchronizes a narrative of the past, present, and future. As one or more of the dimensions of time changes, there are corresponding alterations in the narratives of the self. Moral change in one of the three temporal categories causes a ripple effect in the other dimensions of time. The past is episodic memory, the ability to recall a specific time and place in the past. Episodic memory has its primary locus in the hippocampus in the brain near the amygdale, an almond shaped structure that is the primary locus of emotions. Nerves from the amygdale innervate the hippocampus giving episodic memory emotional impulses and rhythms. Recall is a construction in which emotions and cognitions play important roles. Recollecting the past is a lived temporal, dynamic and emotional process. Emotions give life to our memories, and, who has not felt the tug of the emotions when revisiting a place of great happiness or of sadness? Some individuals are locked into the past when powerful emotional memories from socially threatening experiences in the past intrude into the present. Regulating emotions fails, and thoughts, feelings, and emotions intrude at the most inopportune moments.

The self-control of crying and sleeping is among the first developmental challenges for children. Children who do not learn the regulation of crying and sleeping have difficulties with the other skills. Sleep is a natural part of an infant's day. A stable environment is necessary if children are to learn how to fall asleep. Many parents do not recognize the importance of a stable and predictable world for infants and toddlers. Youngsters with irregular sleeping habits are often irritable, anxious and given to outbursts of crying and emotions. Crying is also a habit that must be brought under control. Crying, especially excessive crying is an exhausting and angry response to something gone wrong in the child's world.

How children fall asleep is a deeply cultural matter. In some cultures, children fall asleep in physical touch with a parent, in other cultures children sleep with siblings, and in our culture children fall asleep alone. Sleep is best understood within the frame of acquiring day-night rhythms. The diurnal rhythm of activity during the day and night is a legacy of eons of evolutionary history. Newborns do not recognize the differences between day and night while four-year-old children sleep for eight hours and through the night. Drifting in and out of sleep is typical for four-year-olds, and during these interludes, some children drift back to sleep while others cannot calm themselves, and wake up. Learning to calm oneself is central to learning to fall asleep and other skills.

Crying is a normal human signal of distress or that something is wrong. Tantrums are not normal. There are children who begin crying and are unable to calm themselves. Crying escalates into a tantrum. Crying peaks at 8 weeks and declines thereafter. Most children replace crying with other forms of behavior that communicate their needs and desires. When the regulation of crying fails, the regulation of emotions is more difficult. The child becomes angry when she cannot be consoled. A tantrum follows with crying, whining, comfort seeking and anger leading to running away, resistance and falling down. 
The Marshmallow Test by Walter Michel is vivid testimony to the power of self-control. Three and four-year-old children sit at a table with the test administrator. On the table is a plate with a "juicy" marshmallow. The experimenter says to a three-year-old child, "You can eat it now or get two if you wait until I run an errand". Children display a variety of facial and bodily contortions to avoid eating the marshmallow. Some of the children manage to wait for the full twenty minutes. Fourteen years later, those children who self-regulate are very different from those children who could not self regulate. Those who are able to wait were more popular with their peers, had less trouble delaying gratification, and scored 210 points higher on their Scholastic Aptitude Tests. The longer the children could hold out, the better they did later in life. The Marshmallow Test is an indicator of things to come. Later in life Obama claims to have used cocaine and marijuana while at Pounouhou. Drugs were supposedly his way of handling the stress and uncertainty of adolescence. The evidence for his consumption of illegal substances is weak at best but if it is true, the episodes were few. The guilt his mother encouraged in him was a brake upon his impulses. More importantly, it was likely that during this period that he first began to have the inkling that he had special talents and would one day make a bid for the office of the presidency. (He has never commented on when he first had the idea that he could become president of the United States.

Obama's cool intellect and steely temperament are hallmarks of his personality and relationships with others. In isolation, this façade of temperance leads to indifference and distance from others. He is saved from this choice by the love and caring of his mother and grandparents. They purposefully guided him away from an isolated individualism to caring engagement with others.

\section{Stage III: Courage}

Courage is the emotional strengths necessary to confront adversity in the forms of fear, pain, danger, uncertainty, and intimidation. There are many different kinds of courage: physical, moral, social, political, artistic, athletic and so on. Barack provides an example of the preparation for physical courage.

His mother takes him from the beaches of Honolulu and to Jakarta, Indonesia. It is a jarring change from living with his grandparents. Barack is excited and perpetually curious about all the new sights and sounds he experiences. He loves Jakarta, and he quickly absorbs the world around him. He learns the language in six months along with the bumps and bruises of a schoolboy. The sights, sounds, and the feel of Jakarta excite him. $\mathrm{He}$ is a bright and curious young fellow who feels lucky to live his new life. He learns to eat peppers, dog, snake meat, and grasshoppers.

The expression "preparation for physical courage" is a statement that preparing is often sufficient to eliminate the need for physical courage. Organizations facing fear, pain, uncertainty, intimidation and danger practice how to act in the face of adversity. Learning to be physically courageous is important in where fear and violence are commonplace. Barack learns about preparing for danger living in Jakarta, Indonesia. He comes home with a bump on the head from a neighborhood bully. He tells Lolo, his stepfather, that another boy hit him with a rock. The boy took a soccer ball from Barack and his friends. Lolo comes home the next day with boxing gloves. He teaches Barack how to box and gives him some advice on life. "Only the strong survive", is the way Lolo put it. "It is sometimes not a matter of right or wrong, sometimes it is who is strong." Barack learns that it is important to be prepared for adversity and wrong doers. Lolo tells him stories about life in the army, and he shows Barack the scars from leaches from his time in the jungle. Barrack summons the courage to ask Lolo, "Have you every seen a man killed?" Yes, was the answer? "He was killed because he was weak." Lolo practiced a kind of moral reality.

The bully hit Barack on the head with a rock. It did hurt. It probably hurt his feelings more than his body. The bully was wrong. What should Barack do? Now the question becomes what should Barack do? Now he uses his moral imagination. Barack is a very cerebral and a fine athlete. He is no push over in a fight. Should he become a bully? He thinks about it briefly and discards the idea. He does not experience fear with the heart palpitations, sweating, and dry mouth. His intellect over overrides most fears. Perhaps it is simply a result of his successes.

Obama's resiliency was strengthened by Lolo's instruction in boxing. It taught him that preparation and foresight were important in tests of courage. His preparation for a fight meant that he would not have to fight. He knew what to expect when a bully wants to cause him physical harm, he knows how to respond. This preparation stands him in good stead when he faces the prospect of a deliberate or chance encounter with danger in the future.

Many youngsters live in fear of physical, emotional, and psychological violence. They show quiet courage every day when they take they face bullies and gangs to go school on the bus or train, while they are in school, and to face those same bullies and gangs on the journey home. This courage is the quiet strength to persevere and 
accomplish one's goals. Barack saw courage everyday in the quiet strength of the people around him who everyday went to work and raised their children. Quiet courage is the simple acts of people getting up everyday and doing the things to make the lives of loved ones better. Bullies, gangs, and violence are serious problems for children who face them everyday. In some instances, children need to be taught how to defend themselves and loud courage replaces quiet courage.

Barack Obama's moral self emerges during his elementary school years. He enjoys his elementary school years but not school.

His episodic memory matures and the moral self emerges. Episodic or autobiographical memory of events includes time, place, associated emotions, and contextual clues. Episodic memory is like a scene in a movie, the what, why, when and how are united. Six-year-olds compare present and past events. Increasingly they are adept at making decisions based on past experience. This is Piaget's period of concrete operations when children think in concrete terms. Instruction in school is concrete. The concrete is often overlooked. Children learn to do arithmetic by counting with their fingers. They learn to read by practicing their sounds over and over. The sights and sounds of every day life entice Barack. He enjoys hanging out with his new friends. The sights and sounds of Jakarta are music to his ears. His mother worries more and more about his declining interest in school.

At the same time his mom is worried that she will lose her son to the streets of Jakarta. Her moral outlook is different from those around her, and she knew it. She insisted upon the importance of honesty, fairness and straight talk. She tried to resurrect her Kansas background even though she knew it was not practical. She worried about Barack's health and safety in Jakarta, and finally she made a decision to enroll Barack in Pounohou Prep School in Honolulu.

\section{Stage IV: Love of Knowledge}

His mother nurtured Barack's love of learning and knowledge in Jakarta. He attends the local school but his mom was not satisfied with those schools. She home schooled Barack before there was the concept of home schooling. She acquires a correspondence course to supplement his education and becomes his teacher. His love of knowledge emerges as his mother teaches him in the early morning before school. Instruction was three hours a day, five days a week. Fifteen hours is more direct instruction than the average child receives in a full week. A young, impressionable Barack loves his mother and learns to love learning. Undoubtedly, he did protest getting up at 4 a.m. in the morning but he swallowed it all down, the knowledge, the breakfast, and the love. Occasionally he did drift off to sleep but his mother insisted, and he awakened to learning. He absorbs the character traits of love and knowledge and wisdom without notice. He attends the local catholic elementary school but his interest in being with his new friends is more important than the approval of his teachers.

The cultivation of knowing and believing marks learning in and out of school. Knowledge and belief flow together during instruction. During the early years of school children believe in their teachers as they absorb their A, B, Cs. Later children stop believing in their teachers and they stop learning. The intimate connections between knowledge and belief are ignored because we do not appreciate the importance and complexities of belief. Belief has two forms: believing that something is the case and believing in someone. Believing that is connected to the evidence. As evidence accumulates we go from believing that some thing is true to knowing that it is true. Once upon a time I believed that men could not go to be the moon. Now there is evidence men have been to the moon. Beliefs become knowledge as evidence becomes available. Believing is a powerful form of knowledge because it does not require evidence.

Believing in the teacher is an emotional experience more akin to trust than to cognition. Originally the word belief referred to standing by and supporting the person. Later believing in came to designate believing that the word of the person was true. The power of believing in the teacher is captured in Vygotsky's Zone of Proximal Development in which the child accomplishes more with the help of the teacher than working alone. The same phenomenon is seen in John Dewey's description of a learning activity. When a moral task is well practiced, the learner enters into the flow of the task and is transformed into someone who is passionate about learning. Being home schooled by his mom had a decisive effect upon the young and impressionable Barack. After his elementary school days are over in Jakarta Barrack returns to Honolulu where he stays briefly with his grandparents. They are an embarrassment to him living in a small, cramped apartment. Worse they are disillusioned with each other. Gramps career as salesmen is almost over and he believes he is a failure. Toots, his grandmother, is becoming disillusioned in her job at the bank. She makes more money than her husband and this is humiliating to him. Barack is acutely aware of all of this.

He is a student at Pounohou Preparatory School, a private and prestigious school where wealth and scholarship are norms. Life at Pounohou is an isolated and lonely experience. The racial isolation he feels is real. He is one 
of four African-American students living on campus. His academic achievement at Pounohou is modest and perhaps mediocre. He desperately needs a community. He finds community on the basketball. He has a passion for basketball but is not given playing time on the basketball team. He is a secondary role player who sees little playing time.

Basketball is more important to African-American males than school. In school, they are not treated fairly. On the basketball court, everything is equal. Playing ball allows black males to enter a new reality. The world disappears and the only thing that matters is what goes on within the lines of the game. Playing ball is an acceptance ticket into the black adolescent world. Adolescent males control the world between the lines of a basketball court. Only the rules of the game matter. All other forms of reality are suspended and not relevant. The only thing that matters is playing the game with teammates. Obama's teammates and opponents taught him an attitude that didn't just have to do with the sport. "Respect came from what you did and not who your daddy was.... and something else too, something nobody talked about":

A way of being together when the game was tight and sweat broke and the

best players stopped worrying about their points and the worse players got

swept up in the moment and the score only mattered because that's how

you sustained the trance. In the middle of which you might make a move

or a pass that surprised even you. So that even the guy guarding you had

smile, as if to say, "Damn..." ...I could find a community of sorts, with an

inner life all its own. (pp. 79-80)

Playing basketball creates a sense of community and belonging. While playing the game the past drops away, and the future does not matter, to be in the present and to perform is all that counts. It requires courage to set your fears aside, put your game at risk, and the disciplined temperance to accept the losses and embarrassments that are an inevitable part of the game. What makes it all worthwhile is that when the game begins, ego disappears, and movement fades into the rhythm of the team. The basketball court is a needed refuge in the continuum for adolescents.

Obama's moral self is unique. Two systems guide the moral self an emotional and a cognitive system. Emotions and intellect work in tandem to make the appropriate decisions at the right time and in the right amount. The system works differently for Barack because he is a supremely intelligent young man. His exceptional intelligence is the default system for making decisions. In other words, he is guided and driven by his exceptional intellect. Moral judgments are usually made by the emotional system and the cognitive system provides a rationale for decision-making. Obama is different. His intelligence makes the moral decision, and his emotional system provides confirmation of the rightness of the judgment.

His mom sits down to talk to him about his future. College applications are undone. Barack is thinking about luck and his mom talks of responsibility. She uses her tried and true method of making Barack feel guilty. As she put it guilt was an under rated emotion. According to her, a healthy dose of guilt never hurt anybody, its what the world is built on.

Resilience is ordinary and deeply connected to morality. Children faced with poverty, dysfunctional families, drug abuse, and prenatal are not doomed. They have a chance, a very good chance. Negative factors can be buffered by the support of an adult role model. One person makes a difference in a child's life. One person, not necessarily a family member, makes it possible for a youngster to survive and live a productive life. Anyone who makes a decision to make a child's life better engages in moral activities that change life of the child and the person who cares. A caring relationship buffers the lives of all who are involved.

Barack's resilience is strengthened by his mother's periodic absence from his life. Her absence strengthened his resolve for success and achievement. He finds himself striving for success to please someone who loved him deeply and is not present. It is so much harder and perhaps impossible to please someone who is only present in spirit and memory.

\section{Stage V: Justice and Social Justice}

The yearning for justice is universal. Chimps rebel when rewards are not distributed fairly. All four-year-old children insist upon fairness. Justice is valued by all cultures, and some have called justice the master virtue, the most important of all the character traits. Justice, like the other virtues, is learned in the ebb and flow of the activities of daily life. Courage is learned by doing courageous things and justice is learned by doing just things. 
According to Solomon (1995) justice is an emotion to be cultivated from our natural feelings for our fellows and molded into the sturdier mold of character. Emotions have duration, a judgment of right or wrong, evaluation, a sense of responsibility, and a strategy to reach a goal. Justice is a blend of compassion, pride, loyalty on the positive side and anger and vengeance on the negative side. Compassion is a feeling for another who is in a serious or grave condition, and it extends to those who we do not know and have not met. Pride is a feeling of accomplishment directed toward the self, and is correlated with self- esteem and dignity. Loyalty or commitment to family, friends, neighbors, and others makes us members of a community and a decent person. The negative emotions of anger and vengeance are also a part of the feeling of justice. Anger accuses someone of an injustice, it is an offense taken personally. When we care about the offense, the anger is amplified, and violence and vengeance are possible. Vengeance is a variegated and dangerous emotion; "There is no denying the satisfaction that pleases us when the bad guys get the comeuppance they deserve." Yet there is also denying the cyclical cascade of offense and retribution are a part of vengeance.

A just character is formed from engaging in just activities. Social justice activities are the focus of this discussion rather than individual calculations of justice. The standard approach to moral development and justice focuses upon the individual making moral judgments in response to the moral dilemmas of Lawrence Kohlberg. In a moral dilemma, the individual makes a choice and uses cognitive skills to weigh the moral gravity of the outcomes. Kohlberg's approach to understanding moral development highlights individual cognitive development. Here, the group and emotions are the center of attention in this discussion of justice. The shift from the individual to the group includes a corresponding shift from the cognitive to the emotional. The development of groups is highlighted because groups are integral to education and moral development.

Barack Obama, a neophyte community organizer, arrives in Chicago in August 1983 intending to make it is his new home and a platform for elected office. He has read about the great migration of African-Americans to Chicago in the forties, fifties, and sixties. The city that accepted so many must have a place for him. His decision to become a community organizer in Chicago speaks to his political ambitions and his need for community. What better way to find community than by becoming a community organizer? Of course, he knows nothing about community organizing. Yet, he feels the distant ache of not having a community to call his own. Deep within, he harbors doubts about his ability to find a place in the African-American community.

He has never had a home, a place with family, friends, neighbors, and a place of worship, a place to call his own. He has never felt the tug of loyalty that connects him to a place where he feels at peace. What better strategy than getting paid to find what you are looking for? He always wanted to be a part of a community, a place that affirms without asking and supports without thinking.

His career as a community organizer gets off to a rocky start. Social justice is the heart beat of community organizing, and uses groups to achieve justice. Marty, his new boss is a veteran in the organizing struggle. Marty comes across as cynical at first but perhaps it is better to describe him as realistic. "Barack if you are going to do this work, you have to stop worrying if they will like you, they won't." Issues, action, power, self-interest are his touchstones of organizing. Barack's first job was to go out and interview a list of people to find their self -interests. People become involved because it is in their self-interests. Once he found an issue, Barack could lead his new group into action.

Groups are the principal tools of social justice. Obama recognizes early on that if he is to be successful as a community organizer he needs the support of groups in the black community. He does not yet know how to mobilize and organize a group. His first efforts are aimed at working with existing secular and religious groups. No, was their uniform answer. Each group had its own interests, agendas, and leaders. They had no incentive to change at Barack's request. He struggles as a community organizer until he forms a group that will change the community and Barack Obama.

\section{Obama's Army: Group Development and Social Justice}

Obama's army, a small group of volunteers, evolves from a collection of individuals into a group with a shared vision of social change. Will, Angela, Mona, Shirley and Barack fashion a collective vision of their goals. They start Barack on the road to success as a community organizer. Angela, Mona and Shirley are independent and spirited women without husbands that raise sons and daughters, juggle part time jobs and business schemes, and organize Girl Scout Troops, fashion shows and summer camps. Will, the other man in the group, is a Vietnam Vet who began a career in banking, was laid off, and became a minister. He wears a collar, unlike most African-American protestant ministers, to inform the community where he is coming from.

This group of five goes through a predictable group development sequence of forming, storming, norming, and flowing as they learn to care for each other, and achieve a small measure of social justice. A group is an organic organization that grows in stages. When they achieve their collective goals and the stage of flowing the emotions 
of compassion, pride, and loyalty are freely expressed and feelings of anger and vengeance are set aside. Obama is the leader of the group. His success is doubly important because as his circle of groups widens, he becomes, for the first time, a respected member of an African-American community.

In the beginning, he sees Chicago as a community where a dismal present crowd out the future, and the community is without hope. In its first stage of forming the group confronts the dismal realities of black Chicago, and they want to change their lives and the community. Obama reflects on the voices he hears and surmises,

When they talked of the future certain disquiet entered their voices.

So, despite the deserved sense of accomplishment these men and women felt,

despite the irrefutable evidence of their own progress, our conversations were

marked by another more ominous strain, The boarded-up homes, the

decaying storefronts, the aging church rolls, kids from unknown families

who swaggered down the streets - teenage girls feeding potato chips to crying

toddlers... all of it whispered paintful truths, told them, the progress they'd

found was ephemeral, rooted in thin soil; that it might not even last their

life time. (157)

Their collective work begins in the Altgeld Projects on the southern edge of Chicago. Alttgeld is a two thousand-apartment project arranged in a series of two story buildings. The Calumet River runs nearby where men fishing pays little heed to the discolored fish especially if they need to eat. To the west is the Calumet landfill, the largest in the Midwest. A sanitation plant belches fumes into the air that they could not see. They smell the stench from the plant and they did complain but to no avail. Altgeld was always in a state of disrepair. The ceilings were crumbling, pipes burst, toilets backup and the lawns were mud puddles. The Chicago Housing Authority had given up on Altgeld. Nearby was mile after mile of closed factories that once nurtured the dreams of countless migrants.

The second stage of group development is storming or conflict. Obama's group organizes around the issue of police protection and service to the community. He turns to the local ministerial group for help, and they reject him. Thinking of their individual interests, the ministers reject the idea of coordinated action. One failure at organizing follows another. Their organizing effort does not have a clear goal or message that resonates in the community. The members of the group agree about neither means nor goals. Conflict is inevitable. The conflict in the group focuses their complaints about Marty, Obama's boss. They complain Marty didn't care about Altgeld, their community. They insisted Marty was arrogant but most of all they worried about the lack of jobs at the job bank. The job bank was a federally funded program to help residents find jobs. Two months after the start of the job bank, not one person had found a job. They complained that the grant for $\$ 500,000$ had gone to Marty and his people. Angela's frustration was at a boiling point after a meeting with the local union. She recognized that the union was not interested in the plight of black people...Things became so bad that Angela, Shirley, Mona, Will, and Mary wanted to quit. To their plea to quit, Barack responded:

"Let me ask you what is going to happen to those boys out there?" "No, I'm

Asking you a question. You say you're tired, the same way most folks out here

are tired. So, I'm trying to figure out what's going to happen to those boys.

Who's going to make sure they get a fair shot?

Barack reminds the group about the importance of social justice, and convinces them they have to go on. They stop, and start to make plans. Things drift along until Will suggests they take their organizing effort to the street. Soon they bring together thirty volunteers who were willing to work for a cup of coffee. The group now has a new goal and a means to reach that goal.

Stage three, norming, begins as the group develops norms and goals valued in the community. The weariness of winter and no progress forces Obama into the lives of others. He spends time in the community center sharing stories with people about their lives. He listens to their stories. Each is a tale of challenge, struggle, and quiet courage. Obama sees that each person takes on the responsibility for caring for another. He tells his new friends about his mother and grandparents, Waikiki Beach, streets of Djakarta, and going to school at Punahou. The weaving together of these stories was the beginning of a community. You can always find community if you dig deep enough. This was the message that he took away from his conversations. 
Obama realizes he does not have the power to make changes in welfare policy, create jobs or increase funding for the schools. He could help improve services at Altgeld, the housing project, where he is working. Getting the toilets fixed, the windows repaired, and the heaters working are attainable goals. It takes him more than a year before it dawns on him that success is choosing realizable goals.

The turning point comes at a tenant-organizing meeting, Linda asks him about a notice informing the public about asbestos in the Altgeld Public Housing. Sadie volunteers to call the management at Altgeld to learn if all the apartments were free of asbestos? A lack of a satisfactory response from the Chicago Housing Authority moves the group to action.

Obama's army, a group of mostly women, goes downtown to meet with the head of the Chicago Housing Authority (CHA). "Obama's army" is what Dr. Collins, principal of the elementary school, calls them as the small, dispirited group boards the bus taking them to the confrontation with the Chicago Housing Authority (CHA). All seemed lost when they arrived; the receptionist informed them she would call security to have them removed from the premises if they did not leave. At that moment the elevator opens, and television crews show up and begin to film the encounter. Sadie, a parent, with a quivering voice gives a television interview recounting their efforts to have their apartments inspected for asbestos. On the ride, back to Altgeld everyone is excited, they all want to talk. Their excitement multiplies when Sadie's face appears all over the evening television news. This meeting signals his first real success as a community organizer, and it has a profound impact upon Obama.

I changed as a result of that bus trip, in a fundamental way. It was the

sort of change that's important not because it alters your concrete

circumstances in some way (wealth, security, fame) but because

it hints at what might be possible and thereby spurs you on, beyond

the immediate exhilaration, beyond any subsequent disappointments,

To retrieve things that you once, ever so briefly, held in your hand. (p.242)

Stage four, flowing, is the moment when the group crosses the threshold of shared responsibilities with a moral vision. Obama is offered an opportunity to leave Altgeld and to take another assignment working in Gary, Indiana. He refuses, explaining to his boss, Marty, that he did not understand the importance of loyalty to others. The people in Obama's army are his friends and community. The first ones he has ever had.

Place kind of grows on you, Will said to Obama. He nods, Yeah, Well it does. Will took a big slurp of his soda and let out a belch. Three years ain't that long to be gone, he said. "How do you know I'm gonna be back?" "I don't know how I know, he said, pushing away from the table. Without another word, he went to wash his hands, got on his bicycle and went peddling down the street.

Barack's moral self-changed. Character, social justice, and his moral self came together. Will saw this before Barack did. Barack remembers his friends from California, and imagines them living in Chicago. He imagines he is one of the thousands of migrants from the south seeking the promise land. He imagines watching Regina jumping rope on the sidewalks. Frank is in his baggy suit standing in front of the Regal Theatre waiting to catch a glimpse of Count Basie or Billie Holiday. Obama is a changed and different man; he is rare combination of visual and moral imagination, exceptional language skills, and intellect. His visual imagination grounds his thinking in daily practice.

From a group perspective, new forms of morality are continually being created. Modern social life with its increasing complexities and fragmentaion is creating new and different moral relationships. Human beings are moral creatures constantly creating new groups and social relationships. The usual moral relations are with mothers, fathers, siblings, family, friends, peers, same, and different sex partners, and leaders. Today, opportunities for moral relationships in school, community, sports, arts, music, church and the internet are easily available. New forms of relationships are evolving in cyberspace. Whatever their origins groups go through a predictable sequence of forming, storming, norming, and flowing. When groups achieve flow, morality emerges in the changed relationships between members of the group. Social relationships give way to moral relationships when members take the responsibility to make other members of the group better. Groups are constantly being created, merge, diverge, and sometimes conflict with other moral groups. The moral landscape changes with the emergence and disappearance of different moral groups.

The creation of groups is the heart beat of community organizing with its intention of changing the moral landscape of a community. Barack is a more resilient politician as a result of his experiences as a community organizer. He now fully understands the role of the group in social justice. Political power flows from the group. 
He now sees what and where are the levers of power in all communities. Power is in the shared visions and purposes of groups be they young, old, white, black, Jew, Moslem, or Christian. Barack finds acceptance in his work in Chicago as a result of being immersed in the lives of others and their daily struggles.

\section{Stage VI: Spirituality}

"Thank you, Jesus, thank you Jesus you brought me, yes you brought from a mighty long way." Every Black church in America resonates with this hymn and its sentiments. The church gives food to the hungry, clothing to those without, hope to those in despair, and a spiritual community to those who accept it.

Spirituality, religion and community are all but synonymous in the African-American community. America is the most religious country in the western world, and African-Americans are amongst its most fervent believers. In 2008 eighty-eight percent of African Americans believed in God with absolute certainty, and sixty five percent go to church a least once a month. Spirituality is central to the church and the church is the heart beat of the community.

Why do we have religion? Religion increases the likelihood of survival while answering existential questions about the meaning of life as it brings family and community together. Questions about this and other possible worlds are answered in churches. In an uncertain world in which there are periodic cycles of crises, deprivations, and warfare, religion strengthen bonds with friends, family, and clans, and communities. An array of rituals, intermarriage, gift giving, and ecstatic rituals bring church and communities together.

The question of why we have religion makes no sense in the African-American community. The church is the center of the African-American community. The liturgy, music, rituals, and literature of the Church build upon the spirituality in the community. At the heart of this experience is a spirituality that flows into every aspect of community life. The emotion of hope is central to the African-American religious experience and the community Hope is an emotional belief in a positive outcome in life and persevering in the face of obstacles. Within the church hope is as much a part of the liturgy as is the trinity. Spirituality and hope join the sacred and secular that flows from the past to the present and into the future.

Obama worries about his lack of a connection to a community of faith in Chicago. The church is the center of the African-American community with its spirituality and involvement in every part of the community. He must find a church home if he is to be a member of the community. His success as a community organizer depends upon having religious roots and connections in the community. Politics, religion, and spirituality converge in the African-American church. Barack is impressed by the social justice stance of the Reverend Jeremiah Wright, and his ability to unify the disparate elements of the community. Barack begins attending, Trinity Baptist Church, and finds a fulfillment and contentment in the services. Yet he worries about conversion becomes he wonders if his new religious fulfillment is an expedient way of meeting his other needs. He wonders if his new spirituality is political opportunism?

The Audacity of Hope is the title of Reverend Wright's sermon and he is in fine form on this Sunday morning. His sermon is a flow of stories beginning with a passage from the book of Samuel in which Hannah wept before god because she was barren. Next there is the story of a painting of a battered woman playing a harp while the world below sinks into anarchy. The good people are down trodden in the excesses of capitalism. South African apartheid is just the most recent example of the sins of racism and capitalism. Reverend Wright recounts the trials and tribulations of the members of his church. The stories of the bible, and the messages from a work of art are the background for the trials and tribulations of the poor and politically dispossessed who suffer from inequalities. Hope is the antidote to the despair that is everywhere. Hannah, the harpist, and all who suffer have hope as their way of going on.

Hope like most emotions has a theme, an object, appraisal, and an action tendency. The core theme of hope is that there will be an amelliaration of a dreaded outcome. We should not hope for things that are certain or should we hope for things that are improbable. This opens the way for religion. Hoping does not have to be practical. Hope can be daring and risk taking. Obama favors the phrase the audacity of hope and conveys the idea that hope is startlingly strategic. It allows the setting of goals that mark a strategy to tip the levers of power.

The self disappears in spirituality. The spiritual experience has its most profound expression when the self is not engaged. What happens when the self is not engaged? The unconscious comes to the fore. The unconscious is not blind, and its goal is the integration of the believer into the community. Spirituality or the sharing in the spirit defines the community, and at other times membership in the church defines the community. Spirituality contributes to resilience of the individual. The evidence is overwhelming that churchgoers benefit physically, socially, economically, and spiritually. Religious belief is adaptable because it answers questions that have been with us since the beginning of time. 


\section{Conclusions}

This essay began with the goal of framing a theory of moral development that would cast a positive light on the development of African-American children. The first challenge was to steer clear of the slippery slope of relativism in which anything goes. Instead the Aristotelian virtues, a set of character traits, were chosen as the beginning point. These character traits are found world-wide and respected in all cultures. There is worldwide agreement that loves and caring, temperance, courage, love of learning, justice, and spirituality is central to the development of a decent human being.

The second challenge was to avoid the pitfalls of a mechanical and positivist view of character development. This theory breaks with the tradition of emphasizing cognition and emphasizes emotions as the foundation and beginnings of character. The great debate about the primacy of cognition or emotion in making moral decisions is over. The issue is now settled and we know that emotions come first in decision making and cognition provides a rationale for the decision. Emotions display a unique form of intelligence and are not simply brute passions that sweep over us. Emotions include feeling, direction, indicate responsibility, strategies, and goals.

The third challenge was the concept of the development of the moral self and how it tells stories of increasing moral complexity. The self is not a distant observer but represents a moral being engaged in the world through the moral emotions. The moral self originates in the love and caring of infancy. Later the moral self extends its reach in learning the complexities of temperance and self-control. The moral self tells stories about the process of development. At first the stories of the moral self are in the present, later the past and the present, and with adolescence the moral self begins to consider the future and the distant future.

This framework of character and the moral self permit us to see Barack Obama in a different way. Within this new frame the source of Obama's insights into the American polity is clear. He recognized before anyone else white or black that a majority of Americans would vote to make him president. Racism did not blind him prejudice because he experienced what most Americans cannot imagine. He saw the unconditional love of his white mother for his black father. His moral self does not feel the tugs of prejudice and race as he looks within his family. He does not see the racial divisions that Americans take for granted. In the process, he also demonstrates that his bi-racial background is an asset in understanding the world. This, too, is a new idea and a challenge to the prevailing ethos.

Famously, Martin Luther King, Jr. In his 1963 speech on the Washington Mall asked whites to judge his children by the content of their character. Barack Obama turned this statement up side down. He, a black man, judged the character of whites. He understood the character of white people, and "knew" they would support his bid for the presidency. His moral self sensed a path covered over with the injustices of centuries of racism and pain. He stands astride the racial divide and sees the past and present and a different future

\section{References}

National Research Council. (2000). Acquiring Self Regulation, In J. P. Shonkoff and D.A. Phillips, (Eds.), From Neurons to Neighborhoods: The science of early childhood development, National Academy Press, Washington, D.C.

Nussbaum, M.C. (1988). Non-Relative Virtues: An Aristotelian Approach, In P. A. French, T. E. Uehling, Jr., H. K. Wettstein (Eds.) Midwest Studies in Philosophy Vol. XIII, U. Notre Dame Press, Notre Dame, IN, Notre Dame Press. https://doi.org/10.1111/j.1475-4975.1988.tb00111.x

Obama, B. (1995). Dreams from My Father, A story of Race and Inheritance. https://doi.org/10.5860/choice.33-3527

Solomon, R.C. (1995). A Passion for Justice: Emotions and the origins of the social contract, Lanham, Md, Rowman and Littlefield Publishers, Inc.

\section{Copyrights}

Copyright for this article is retained by the author(s), with first publication rights granted to the journal.

This is an open-access article distributed under the terms and conditions of the Creative Commons Attribution license (http://creativecommons.org/licenses/by/3.0/). 